\title{
REVIEW PAPER \\ Fibroadenomas of ANOGENital MAMMARY-LIKE GLANDS: FROM EMBRYOGENESIS ANOMALY TO APOCRINE ORIGIN
}

\author{
Cornelia Amalinei, Simona E. Giusca, Irina D. Caruntu
}

"Grigore T. Popa” University of Medicine and Pharmacy, Iasi, Romania

\begin{abstract}
Mammary-like anogenital fibroadenomas are rare entities within the wide spectrum of female genital pathology. Our paper provides an up-to-date review, by systematization of the concepts and controversies, from the origin to the development and the diagnosis of the lesion. The theories pertaining to its histogenesis incorporate its debated origin of ectopic mammary-derived lesions, of cutaneous apocrine, eccrine, sebaceous, and mammary-like anogenital glands. Although rare, both clinicians and pathologists should consider this lesion type within the differential diagnosis of anogenital pathology, regardless of the woman's age, and pathological confirmation is mandatory to exclude the possibility of other tumours, including malignancy. Immunohistochemistry may represent a useful tool in tumor characterisation and in differential diagnosis.
\end{abstract}

Key words: ectopic mammary-derived lesion, immunohistochemistry, mammarylike anogenital fibroadenomas.

\section{Introduction}

Anogenital pathology comprises mainly epithelial tumours, squamous cell carcinoma representing $80 \%$ of them [1].

Mammary-like adenomas are unusual anogenital tumors [1]. The histological origin of these lesions is controversial, including postulation of ectopic mammary-derived lesions [1], cutaneous apocrine, eccrine, sebaceous, and mammary-like anogenital glands [2].

The development of an accessory breast tissue is attributed to the failure of regression of milk lines remnants during embryogenesis. The accessory breast can develop anywhere along the milk line, extending from axilla to the groin [3]. An extremely rare presentation consists of a vulvar accessory breast [4]. The literature review identified mainly unilateral or bilateral location within labium majus.

Relatively recent studies have found that the tumors previously thought to be apocrine are currently considered as derived from anogenital mammary-like glands and are termed mammary-like glands adeno- mas $[5,6]$. The locations are similar to the common distribution of mammary-like glands (labia minora, labia majora, fourchette, and clitoris) [6].

Our review of the literature highlights the histological criteria which support the origin hypothesis within mammary-type anogenital glands versus embryological remnants and provides a synopsis of tumor specific clinical and histopathological features.

\section{Embryological update}

The anogenital adenoma diagnosis is entitled to a particular consideration due to its rarity and due to its hypothetical origin either within anogenital sweat glands, or either ectopic mammary tissue, as a result of embryogenesis anomalies [2, 3].

A brief embryological update is useful in understanding the mechanism of development of anogenital mammary ectopic tissue.

The mammary glands are modified apocrine glands arising along the mammary ridges which appear on either side of the body, persisting only a short 
period. The mammary glands begin their development during the fourth week of embryogenesis and extend as two surface thickenings from the axillary to inguinal regions [7]. Remnants of these ridges can result in an arborizing network of canals, as the origin of aberrant lactiferous ducts in various anatomical locations in the form of ectopic breast tissue [7].

\section{Aberrant breast tissue}

Aberrant mammary tissue occurs in 1-6\% of the population, being more prevalent in women in axilla and in upper umbilical scars location $[3,4,8]$. Supernumerary breasts or nipples, polymastia and polythelia may develop from extramammary buds and rarely from tissue displaced from these ridges. Frequently, as a result of hormone-induced swelling, they manifest during pregnancy and lactation [3].

Less commonly, accessory breasts appear in locations outside of the mammary ridges, such as face, posterior neck, chest, middle back, buttock, flank, hip, posterior and/or lateral thigh, shoulder, and upper extremities [3, 4].

The ectopic breast tissue has similar hormone-induced histologic changes during puberty and pregnancy, due to stimulation of their hormonal receptors $[7,9]$. The hormonal regulation can lead to the potential development of tumoral proliferations analogous to those diagnosed in normally localized mammary tissue [10].

\section{Historical records}

A completely formed mammary gland tissue arising in the vulvar region was firstly described in a 30-years old woman, in the left labium majus, in 1872, as "mamma erratica" [1]. The tumor was located in the inner aspect of the left labium majus and was described as large as a "goose egg" and pedunculated [1]. It had been noticed at birth and showed cyclic changes. The tumor showed central erosion and elimination of a milky secretory product. The nipple was microscopically identified in the center of the eroded area [1].

\section{Anogenital sweat glands}

The concept of vulvar lesions derived from milk lines rudiments has recently been challenged by the incidental identification of anogenital sweat glands in the interlabial sulcus $[2,5]$. These are related to eccrine or apocrine glands, being composed of mammary-like ducts with a prominent basement membrane and a dense or loose stromal cuff $[2,5]$.

\section{Controversial hypothesis}

The phylogenetic and ontogenetic hypotheses launched at the beginning of the last century have not been confirmed in human embryos, as mammary glands primordial do not extend beyond the axillary-pectoral region [5]. Thus, the hypotheses of development of accessory breast tissue from these anogenital sweat glands or from caudal remnants of the milk lines are dismissed and lesions such as fibroadenoma, lactating adenoma, hidradenoma papilliferum, hidrocystoma, extramammary Paget's disease, and invasive adenocarcinoma are considered as originating from mammary-like glands [5].

\section{Literature synopsis}

A synopsis of the main characteristics exhibited by 30 well documented reports of 92 cases of mammary-type fibroepithelial vulvar neoplasms is shown in Table I, exhibiting an extremely variable age at the moment of diagnosis and surgical excision (17 to 90 years) and a large variability of the tumor size $(0.7$ to $40 \mathrm{~cm})$.

\section{Clinical presentation}

The anogenital mass may request clinical examination due to discomfort felt by the patient or may only become noticeable if it significantly increases in size. Other reported symptoms include pruritus and bleeding [6].

For the clinician, the differential diagnosis of a subcutaneous lump should include benign cystic lesions such as follicular or Bartholin cysts, hidradenoma papilliferum, primary neoplasms of connective and vascular tissue.

The tumors are clinically described as solid, ulcerated, or cystic [6].

The outcome is generally good after complete surgical excision and the risk of recurrence is low, excepting phyllodes type tumours and bilateral location within the vulva $[3,9]$.

\section{Histopathologic spectrum}

The microscopic examination performed on routine sections (Professor Cornelia Amalinei, 2013) reveals lesions lined by simple cuboidal epithelium (Fig. 1) and containing both epithelial and stromal components (Fig. 2). The histological components are ducts and lobules in an abundant hyalinized stroma exhibiting focal leaf-like architecture without evident proliferation activity (Fig. 2). The ducts are lined by a layer of epithelial cells with decapitation aspect doubled by a conspicuous layer of myoepithelial cells (Fig. 3), without architectural or cytologic atypia.

Fibrocystic changes, lactating adenoma, intraductal papilloma, and extra-mammary Paget disease had been also reported in vulvar mammary-type tissue $[6,25,30]$. Adenocarcinoma may also arise in vulvar mammary-like glands and has to be differenti- 
Table I. Review of clinicopathological features of benign and borderline mammary-type gland fibroepithelial anogenital neoplasms

\begin{tabular}{|c|c|c|c|c|}
\hline No. & $\begin{array}{l}\text { NUMBER } \\
\text { OF CASES }\end{array}$ & $\begin{array}{c}\text { AGE } \\
(\text { YEARS })\end{array}$ & $\begin{array}{l}\text { SIZE } \\
(\mathrm{CM})\end{array}$ & DiAGNOSIS AND OTHER FINDINGS \\
\hline 1 & 1 & 47 & 3.0 & Fibroadenoma of supernumerary mammary gland tissue in vulva [11] \\
\hline 2 & 1 & 33 & 3.5 & Fibroadenoma in a supernumerary breast of the vulva [12] \\
\hline \multirow[t]{2}{*}{3} & \multirow[t]{2}{*}{2} & 30 & 1.8 & Fibroadenoma of the vulva and bilateral fibroadenomas of the breast [13] \\
\hline & & 48 & 1.7 & Fibroadenoma of the vulva [13] \\
\hline \multirow[t]{2}{*}{4} & \multirow[t]{2}{*}{2} & 24 & 3.5 & \multirow[t]{2}{*}{ Vulvar fibroadenoma from aberrant breast tissue $[14]$} \\
\hline & & 42 & 0.8 & \\
\hline \multirow[t]{2}{*}{5} & \multirow[t]{2}{*}{1} & \multirow[t]{2}{*}{32} & 4.5 & \multirow{2}{*}{$\begin{array}{l}\text { Bilateral fibroadenoma in supernumerary breasts of the vulva, followed by } \\
\text { recurrence }[15]\end{array}$} \\
\hline & & & 2.5 & \\
\hline 6 & 1 & 36 & 1.8 & Fibroadenoma of the vulva [16] \\
\hline \multirow[t]{2}{*}{7} & \multirow[t]{2}{*}{1} & \multirow[t]{2}{*}{20} & 4.0 & \multirow[t]{2}{*}{ Bilateral recurring phyllodes tumor in aberrant breast tissue of the vulva [17] } \\
\hline & & & 2.0 & \\
\hline 8 & 1 & 30 & 4.0 & Fibroadenoma of ectopic breast tissue in the vulva [18] \\
\hline 9 & 1 & 24 & 1.5 & Fibroadenoma of the vulva $[10]$ \\
\hline 10 & 1 & 37 & 5.0 & Papillary apocrine fibroadenoma of the vulva $[19]$ \\
\hline \multirow[t]{2}{*}{11} & \multirow[t]{2}{*}{2} & 17 & $0.7-1.6$ & $\begin{array}{l}\text { Synchronous fibroadenoma phyllodes arising in vulvar supernumerary breast } \\
\text { tissue }(\mathrm{n}=3)[20]\end{array}$ \\
\hline & & 39 & 1.4 & Fibroadenoma phyllodes arising in vulvar supernumerary breast tissue [20] \\
\hline 12 & 1 & 37 & 3.0 & Fibroadenoma of the vulva with papillary and apocrine features [21] \\
\hline 13 & 1 & 34 & 6.0 & Phyllodes tumor in ectopic breast tissue of the vulva [22] \\
\hline \multirow[t]{2}{*}{14} & \multirow[t]{2}{*}{2} & 29 & 1.3 & \multirow[t]{2}{*}{ Fibroadenoma of the vulva clinically presented as cysts $[23]$} \\
\hline & & 42 & 1.5 & \\
\hline 15 & 1 & 63 & 1.8 & Fibroadenoma of the mammary-like glands of the vulva [24] \\
\hline 16 & 1 & 29 & 0.8 & Fibroadenoma occurring in supernumerary breast tissue $[25]$ \\
\hline 17 & 1 & 69 & 2.8 & Phyllodes tumor of the vulva $[26]$ \\
\hline 18 & 7 & $35-84$ & $0.7-6.0$ & Adenoma of anogenital mammary-like glands [27] \\
\hline 19 & 1 & 49 & 3.7 & Phyllodes tumor of borderline malignancy in the labium majus [7] \\
\hline 20 & 1 & 45 & 5.0 & $\begin{array}{l}\text { Mammary-type fibroepithelial neoplasm of the vulva with papillary and apo- } \\
\text { crine features [3] }\end{array}$ \\
\hline 21 & 1 & 46 & 2.0 & Fibroadenoma of the vulva $[28]$ \\
\hline 22 & 1 & 18 & 7.0 & Vulvar fibroadenoma $[8]$ \\
\hline 23 & 1 & NA & 5.0 & Ectopic breast fibroadenoma of the vulva $[29]$ \\
\hline 24 & 46 & $31-90$ & & $\begin{array}{l}\text { Mammary-like gland adenoma of the vulva with cystic, ulcerated or solid } \\
\text { gross features [6] }\end{array}$ \\
\hline 25 & 8 & $30-51$ & $1.5-4.5$ & Fibroadenoma and phyllodes tumors of anogenital mammary-like glands [30] \\
\hline 26 & 1 & 40 & 2.3 & Fibroadenoma of ectopic breast tissue in the vulva [31] \\
\hline 27 & 1 & 30 & $1-5$ & $\begin{array}{l}\text { Multiple synchronous and metachronous fibroadenomas of the vulva }(\mathrm{n}=12) \\
\text { and simultaneous breast fibroadenomas and uterine myoma }[9]\end{array}$ \\
\hline 28 & 1 & 18 & $\begin{array}{c}40 \\
(2000 \mathrm{~g})\end{array}$ & Prepuberatal vulval fibroma with coincidental ectopic breast fibroadenoma [32] \\
\hline 29 & 1 & 46 & 2.2 & Vulvar fibroadenoma (Professor Cornelia Amalinei, 2013) \\
\hline 30 & 1 & 20 & 7.0 & Vulvar fibroadenoma with lactational changes in ectopic breast tissue [33] \\
\hline
\end{tabular}




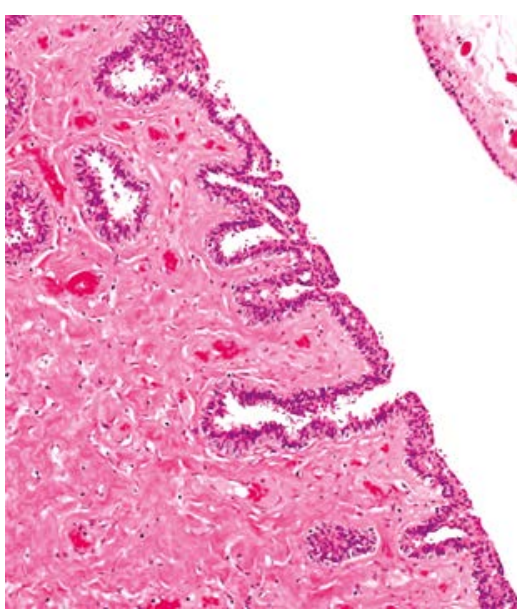

Fig. 1. Intracystic lesion and mammary-type epithelium with basal myoepithelial cells and surface epithelial cells exhibiting characteristic decapitation (HE, magnification $200 \times$ )

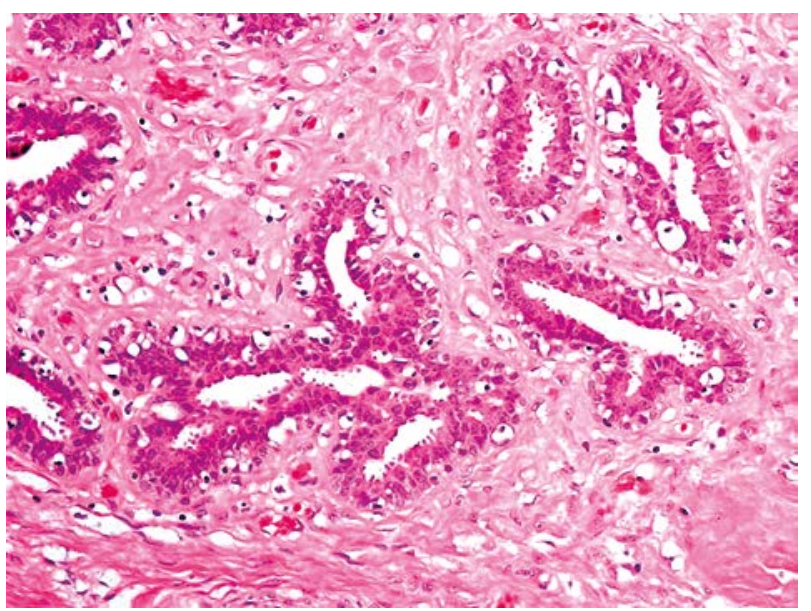

Fig. 3. Ducts lined by epithelial cells with decapitation aspect doubled by conspicuous myoepithelial cells in fibroadenomas of anogenital mammary-like glands (HE, magnification $400 \times$ )

ated from conventional cutaneous adenocarcinoma of apocrine and eccrine origin and metastatic mammary carcinoma $[8,21,28]$.

Extralesional tissue documentation may certify the development of the lesions within mammary-like glands $[3,6,20,25]$. Due to well-circumscribed limits of the lesion and thus the "shelled out" modality of surgical removal, no documentation of the adjacent mammary-like anogenital glands is available in the majority of reported cases $[3,4]$.

\section{Immunohistochemistry contribution}

Immunohistochemistry is useful in tumor characterization, as the luminal cells are generally positive for cytokeratin, estrogen receptor (ER) (Fig. 4), progesterone receptor (PR), and gross cystic disease fluid protein (GCDFP15) (Fig. 5) (Professor Cornelia Amalinei, 2013). The basal layer shows positivity for

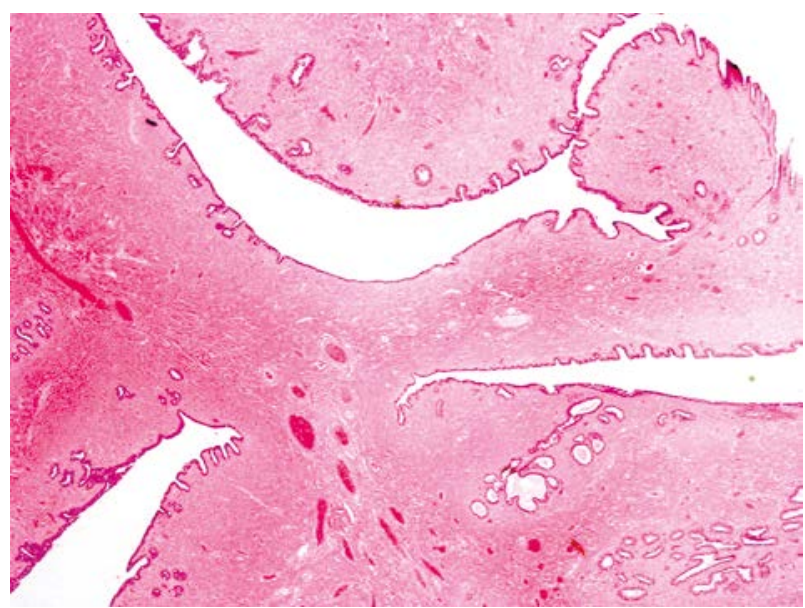

Fig. 2. Mammary-like gland anogenital fibroadenoma containing benign epithelial component and abundant hyalinised stroma; leaf-like pattern (HE, magnification $100 \times$ )

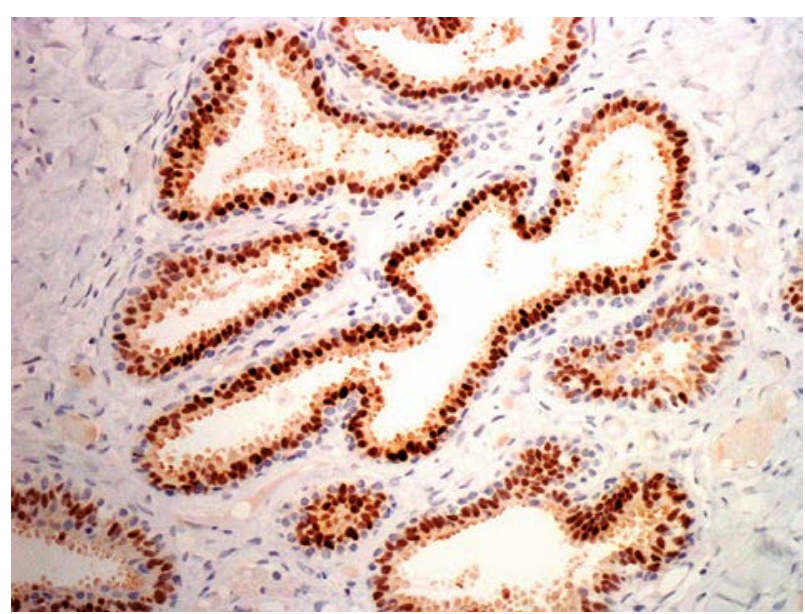

Fig. 4. Positive immunohistochemical reaction with anti-ER antibody in ductal epithelium of fibroadenomas of anogenital mammary-like glands (magnification $400 \times$ )

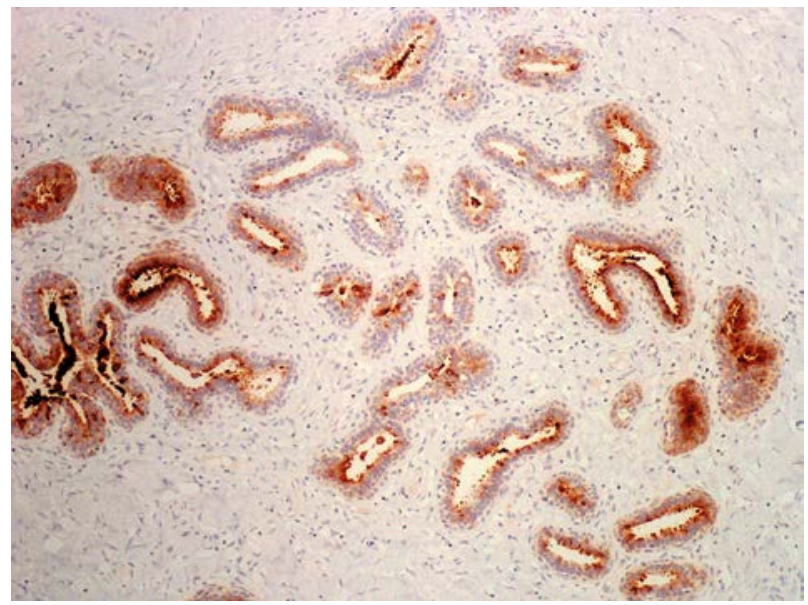

Fig. 5. Positive immunohistochemical reaction with antiGCDFP15 antibody in ductal epithelium of fibroadenomas of anogenital mammary-like glands (magnification $200 \times$ ) 
smooth-muscle-actin (SMA) and S-100, supporting their myoepithelial nature [21].

Furthermore, recent studies demonstrated the expression of a breast differentiation antigen (NY-BR-1) in a vulvar phyllodes tumor and in the neighboring mammary-like glands along with steroid receptors immunopositivity [7], as a supplementary common immunophenotypical feature.

\section{Conclusions}

Although rare, we should consider mammary-like fibroadenomas within the differential diagnosis of anogenital pathology regardless of the woman's age, tumor size, and specific location. The pathological confirmation is mandatory to exclude the possibility of other tumors occurrence, including malignancy.

Further extensive histological research by assessment of the normal adjacent tissue and the development of new molecular markers may provide new evidences to consolidate the current concept of mammary-like gland anogenital adenomas origin within mammary-type anogenital glands, as one of the debated histogenetic hypotheses.

\section{The authors declare no conflict of interest.}

\section{References}

1. Deaver JB, McFarland J, Herman JL. The breast: its anomalies, its diseases, and their treatment. Deaver JB, McFarland J (eds.). P. Blakiston's Son \& Co.; Philadelphia 1917; 79-80.

2. van der Putte SC. Papillary "apocrine" fibroadenoma of the vulva. J Cutan Pathol 1998; 25: 126-127.

3. Carter JE, Mizell KN, Tucker JA. Mammary-type fibroepithelial neoplasms of the vulva: a case report and review of the literature. J Cutan Pathol 2008; 35: 246-249.

4. García JJ, Verkauf BS, Hochberg CJ, et al. Aberrant breast tissue of the vulva. A case report and review of the literature. Obstet Gynecol 1978; 52: 225-228.

5. van der Putte, SC. Mammary-like glands of the vulva and their disorders. Int J Gynecol Pathol 1994; 13: 150-160.

6. Scurry J, van der Putte SC, Pyman J, et al. Mammary-like gland adenoma of the vulva: review of 46 cases. Pathology 2009; 41: 372-378.

7. Giger OT, Lacoste E, Honegger C, et al. Expression of the breast differentiation antigen NY-BR-1 in a phyllodes tumor of the vulva. Virchows Arch 2007; 450: 471-474.

8. Cantú De Leon D, Perez Montiel D, Vásquez H, et al. Vulvar fibroadenoma: a common neoplasm in an uncommon site. World J Surg Oncol 2009; 7: 70-73.

9. Audisio T, Crespo-Roca F, Giraudo P, et al. Fibroadenoma of the vulva-simultaneous with breast fibroadenomas and uterine myoma. J Low Genit Tract Dis 2011; 15: 75-79.

10. Boscaino A, Sapere P, De Rosa G. Fibroadenoma of the vulva. Report of a case. Pathologica 1996; 88: 444-446.

11. Fisher HJ. Fibroadenoma of supernumerary mammary gland tissue in vulva. Am J Obstet Gynecol 1947; 53: 335-337.

12. Siegler AM, Gordon R. Fibroadenoma in a supernumerary breast of the vulva. Am J Gynecol 1951; 62: 1367-1369.

13. Burger RA, Marcuse PM. Fibroadenoma of the vulva. Am J Clin Pathol 1954; 24: 965-980.
14. Foushee JH, Pruitt Jr AB. Vulvar fibroadenoma from aberrant breast tissue. Report of 2 cases. Obstet Gynecol 1967; 29: 819-23.

15. Hassim AM. Bilateral fibroadenoma in supernumerary breasts of the vulva. J Obstet Gynaecol Br Commonw 1969; 76: 275-277.

16. Ahluwalia HS, Gopinath A, Kumaradeva S. Fibroadenoma of the vulva. Med J Malaysia 1978; 329: 215-216.

17. Tbakhi A, Cowan DF, Kumar D, et al. Recurring phyllodes tumor in aberrant breast tissue of the vulva. Am J Surg Pathol 1993; 17: 946-950.

18. Prasad KR, Kumari GS, Aruna CA, et al. Fibroadenoma of ectopic breast tissue in the vulva. A case report. Acta Cytol 1995; 39: 791-792.

19. Higgins CM, Strutton GM. Papillary apocrine fibroadenoma of the vulva. J Cutan Pathol 1997; 24: 256-260.

20. Tresserra F, Grases PJ, Izquierdo M, et al. Fibroadenoma phyllodes arising in vulvar supernumerary breast tissue: report of two cases. Int J Gynecol Pathol 1998; 17: 171-173.

21. Güler G, Usubütün A, Küçükali T. Fibroadenoma of the vulva. Arch Gynecol Obstet 2000; 263: 191-192.

22. Chulia MT, Paya A, Niveiro M, et al. Phyllodes tumor in ectopic breast tissue of the vulva. Int J Surg Pathol 2001; 9: 81-83.

23. Baisre A, Heller DS, Lee J, et al. Fibroadenoma of the vulva. A report of two cases. J Reprod Med 2002; 47: 949-951.

24. Sington JD, Manek S, Hollowood K. Fibroadenoma of the mammary-like glands of the vulva. Histopathology 2002; 41: 563-565.

25. Atwal GS, O'Connor SR, Clamp M, et al. Fibroadenoma occurring in super numerary breast tissue. Histopathology 2006; 50: 511-530.

26. Mariappan MR, Lagera JE, Fadare O, et al. A 69-year-old woman with a vulvar lesion. Phyllodes tumor of the vulva. Arch Pathol Lab Med 2006; 130: e11-e12.

27. Ahmed S, Campbell RM, Li JH, et al. Adenoma of anogenital mammary-like glands. J Am Acad Dermatol 2007; 57: 896-898.

28. Lin WC, Lin WL, Chuang YH, et al. An asymptomatic nodule in the vulva. Clin Exp Dermatol 2008; 33: 523-524.

29. Lucas EW Jr, Branton P, Mecklenburg FE, et al. Ectopic breast fibroadenoma of the vulva. Obstet Gynecol 2009; 114: 460-462.

30. Kazakov DV, Spagnolo DV, Stewart CJ, et al. Fibroadenoma and phyllodes tumors of anogenital mammary-like glands: a series of 13 neoplasms in 12 cases, including mammary-type juvenile fibroadenoma, fibroadenoma with lactation changes, and neurofibromatosis-associated pseudoangiomatous stromal hyperplasia with multinucleated giant cells. Am J Surg Pathol 2010; 34: 95-103.

31. Mahajan Niraj N, Choudrie L. Fibroadenoma of ectopic breast tissue in the vulva: a case report. J Obstet Gynaecol India 2012; 60: 529-530.

32. Zhang J, Chen Y, Wang K, et al. Prepubertal vulval fibroma with a coincidental ectopic breast fibroadenoma: report of an unusual case with literature review. J Obstet Gynaecol Res 2011; 37: 1720-1725.

33. Lev-Cohain N, Kapur P, Pedrosa I. Vulvar fibroadenoma with lactational changes in ectopic breast tissue. Case report. Case reports in Obstetrics and Gynecology; 2013, Article ID 924902, 2013. doi: 10.1155/2013/924902.

\section{Address for correspondence}

Prof. Cornelia Amalinei MD, PhD

"Grigore T. Popa" University of Medicine and Pharmacy

16 Universitatii Street

700115 Iasi, Romania

e-mail: cornelia.amalinei@mbht.nhs.uk 